\title{
Impacts of stratospheric aerosol geoengineering strategy on Caribbean coral reefs
}

\section{Stratospheric aerosol geoengineering}

\author{
Zhihua Zhang
}

Beijing Normal University, Beijing, China

Andy Jones

Met Office Hadley Centre, Exeter, UK, and

M. James C. Crabbe

University of Oxford, Oxford, UK

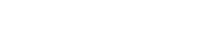

\begin{abstract}
Purpose - Currently, negotiation on global carbon emissions reduction is very difficult owing to lack of international willingness. In response, geoengineering (climate engineering) strategies are proposed to artificially cool the planet. Meanwhile, as the harbor around one-third of all described marine species, coral reefs are the most sensitive ecosystem on the planet to climate change. However, until now, there is no quantitative assessment on the impacts of geoengineering on coral reefs. This study aims to model the impacts of stratospheric aerosol geoengineering on coral reefs.
\end{abstract}

Design/methodology/approach - The HadGEM2-ES climate model is used to model and evaluate the impacts of stratospheric aerosol geoengineering on coral reefs.

Findings - This study shows that (1) stratospheric aerosol geoengineering could significantly mitigate future coral bleaching throughout the Caribbean Sea; (2) Changes in downward solar irradiation, sea level rise and sea surface temperature caused by geoengineering implementation should have very little impacts on coral reefs; (3) Although geoengineering would prolong the return period of future hurricanes, this may still be too short to ensure coral recruitment and survival after hurricane damage.

Originality/value - This is the first time internationally to quantitatively assess the impacts of geoengineering on coral reefs.

Keywords Caribbean Sea, Coral bleaching, Coral growth, Coral recruitment, Hurricanes, Stratospheric aerosol geoengineering

Paper type Research paper

(C) 2018 Crown Copyright. Published in International Journal of Climate Change Strategies and Management. Published by Emerald Publishing Limited. This article is published under the Creative Commons Attribution (CC BY 4.0) licence and as such is compatible with the terms of the Open Government License v 3.0. Anyone may reproduce, distribute, translate and create derivative works of this article (for both commercial and non-commercial purposes), subject to full attribution to the original publication and authors. The full terms of this licence may be seen at http://creativecommons.org/licences/by/4.0/legalcode

This research is supported by National Key Science Programme for Global Change Research 2015CB953602 and the Joint UK BEIS/Defra Met Office Hadley Centre Climate Programme (GA01101).

This paper forms part of a special section "Climate change and biodiversity assets", guest edited by Ulisses Azeiteiro. 


\section{IJCCSM \\ 10,4}

\section{Introduction}

Recent global warming has serious effects on coral reefs, as they are the most sensitive ecosystems on the planet to climate change, and results in widespread bleaching and mass mortality events (Baker et al., 2008). Although coral reefs make up only 0.2 per cent in area of the marine environment, they are among the most biodiverse ecosystems in the ocean, estimated to harbor around one-third of all described marine species (Crabbe, 2009). Coral reefs support the livelihoods of millions of people, especially those engaged in marine fisheries activities, and they also provide some important chemical compounds for many of the world's most prevalent and dangerous illnesses and diseases; e.g., the Caribbean Sea squirt can be used in the treatment of ovarian cancer (Miththapala, 2006). The growth and subsistence of corals depend on many environmental and climatic factors, including temperature, irradiance, hurricanes, calcium carbonate saturation, sedimentation and nutrients (Crabbe, 2009). These factors influence the key physiological processes of photosynthesis and calcification, as well as coral survival, and as a result, scleractinian coral reefs occur only in select areas of the world's oceans. Owing to recent global warming, serious degradation has been observed on many coral reefs worldwide, and the coral cover in the Caribbean has declined in some areas to $\sim 10$ per cent in the early 2000s (Isabelle et al., 2013; Schutte et al., 2010). Some reefs can self-recover, while others need help from artificial restoration, and some are unable to undergo restoration because the substrate or the environment is not suitable for coral growth.

To mitigate against the effects of global warming, a direct approach is to radically transform our societal metabolism toward a low carbon economy; this will require fundamental changes in the design, production and use of products. Owing to the conflict between present abatement costs and future climate benefits, currently there is lack of strong global political will for serious mitigation. Given the extreme risk of an unmanageable temperature path in the future caused by essentially unrestrained fossil fuel burning, geoengineering (climate engineering), which is the intentional large-scale manipulation of the environment, has been suggested as an effective means of mitigating global warming from anthropogenic greenhouse gas emissions. Many of the proposed geoengineering schemes carried out on land or in the ocean are to use physical, chemical or biological approaches to remove atmospheric $\mathrm{CO}_{2}$ (Budyko, 1977; Boucher et al., 2013; Zhang et al., 2015). These schemes are able to only sequester an amount of atmospheric $\mathrm{CO}_{2}$ that is small compared with cumulative anthropogenic carbon emissions. Most of the geoengineering schemes carried out in the atmosphere or in space are based on increasing planetary albedo. The main idea is to reduce the amount of sunlight reaching the Earth to balance long-wave greenhouse gas forcing (Zhang et al., 2015); for example, to simulate the effects of large volcanic eruptions (Mount Pinatubo in the Philippines in 1991), one proposed stratospheric aerosol geoengineering scheme is to inject 5 megaton (Mt) of sulfate aerosols into the stratosphere to block incoming sunlight (Crutzen, 2006; Robock et al., 2009; Israel, 2010). It would be very effective at back-scattering a portion of the incoming sunlight, thus cooling the surface. Annual costs for delivering these sulfate aerosols are estimated to be just \$2-8bn (Kravitz et al., 2011; Zhang et al., 2015). Stratospheric aerosol geoengineering has low costs, and short lead times for technical implementation and can rapidly mitigate climate change with significant global mean temperature decreases, so it is viewed as one of the most promising geoengineering approaches to be implemented in the future. Until now, there is internationally no quantitative assessment on the impacts of geoengineering on coral reefs. In this study, we will evaluate the consequences of the impacts of a stratospheric aerosol geoengineering scheme on Caribbean coral reefs. 


\section{Study region and climate modeling}

In this study, we will concentrate on Caribbean coral reefs, which are severely threatened by climate-induced ocean warming (Hoegh-Guldberg, 1999). There are about 26,000 $\mathrm{km}^{2}$ of coral reefs in the Caribbean region, approximately 7 per cent of the shallow reefs of the world (Burke et al., 2011). These reefs provide numerous benefits to nearby human communities, e.g. shoreline protection from the hurricanes. However, the Caribbean Sea is generally regarded as the reef region with the lowest resilience (Gardner et al., 2003). Caribbean coral reefs have experienced unprecedented changes in the past 40 years. The coral cover has fallen sharply, from about 50 per cent in the 1970s to 10 per cent in the first decade of the 2000s (Gardner et al., 2003). It has serious consequences for reef biodiversity, ecosystem functioning and related environmental services.

According to the 2013 Fifth Assessment Report (AR5) by the Intergovernmental Panel on Climate Change (IPCC) of the United Nations, the concentration of carbon dioxide $\left(\mathrm{CO}_{2}\right)$ in the atmosphere increased from a pre-industrial value of about $280 \mathrm{ppm}$ to $391 \mathrm{ppm}$ in 2011. In 2015, the concentration reached more than 400 ppm (Zhang et al., 2015). Representative Concentration Pathways (RCPs) are referred to as pathways of projections of future atmospheric greenhouse gas concentrations. RCP4.5 is named after a possible range of radiative forcing values in the year 2100 relative to pre-industrial values $\left(+4.5 \mathrm{~W} / \mathrm{m}^{2}\right)$ owing to the increasing concentrations of atmospheric greenhouse gases. This stabilized forcing reflects a $\mathrm{CO}_{2}$ equivalent concentration of $650 \mathrm{ppm}$. To compare with the RCP4.5 scenario, we assume stratospheric aerosol geoengineering in 2020-2069 with daily injections of $\mathrm{SO}_{2}$ at a rate of $5 \mathrm{Tg} \mathrm{\textrm {SO } _ { 2 }}$ per year, which is just one of the standard experiments in the Geoengineering Model Intercomparison Project (GeoMIP) (Kravitz et al., 2011). In this paper, we will use HadGEM2-ES climate model simulations of stratospheric aerosol geoengineering to model and assess the impacts of stratospheric aerosol geoengineering on coral reefs in the Caribbean Sea by comparison with the RCP4.5 scenario.

\section{Coral bleaching}

The predominant source of nutrition for corals comes in the form of photosynthetic products produced by the zooxanthellae. Under unusually high sea temperatures, coral bleaching occurs when corals lose their zooxanthellae. Coral bleaching may result in coral mortality, catastrophic loss of coral cover and loss of critical habitat for associated reef fishes and other biota (Eakin et al., 2010).

Based on HadGEM2-ES climate model simulations of sea surface temperature (SST), we can project changes of coral bleaching regions under stratospheric aerosol geoengineering (left column) and RCP4.5 (right column) scenarios. Figure 1 shows coral bleaching area in 2030, 2050 and 2069, respectively. Under the RCP4.5 scenario, in the northern Caribbean Sea, coral bleaching will occur with high probability, while in the southern Caribbean Sea, coral bleaching will not occur, except for some small regions near the southern coastline. However, if a stratospheric aerosol geoengineering scheme mentioned above is implemented during 2020-2069, it is predicted that coral bleaching will not occur, except for some small regions near the southern coastline or east of Florida. This is because stratospheric aerosol geoengineering can control SSTs throughout almost all of the Caribbean Sea below the thermal threshold of corals. In summary, implementation of stratospheric aerosol geoengineering could significantly mitigate coral bleaching.

\section{Hurricane impacts and coral recruitment}

Hurricanes and tropical storms in the Caribbean Sea can cause considerable damage to coral reefs with great destruction of corals. Across the Caribbean Sea, coral cover is reduced by 17 
IJCCSM

10,4

\section{6}

Figure 1.

Projected coral bleaching area under stratospheric aerosol geoengineering (left column) and RCP4.5 (right column) scenarios in 2030 , 2050 and 2069, respectively

\section{Geoengineering}

RCP4.5
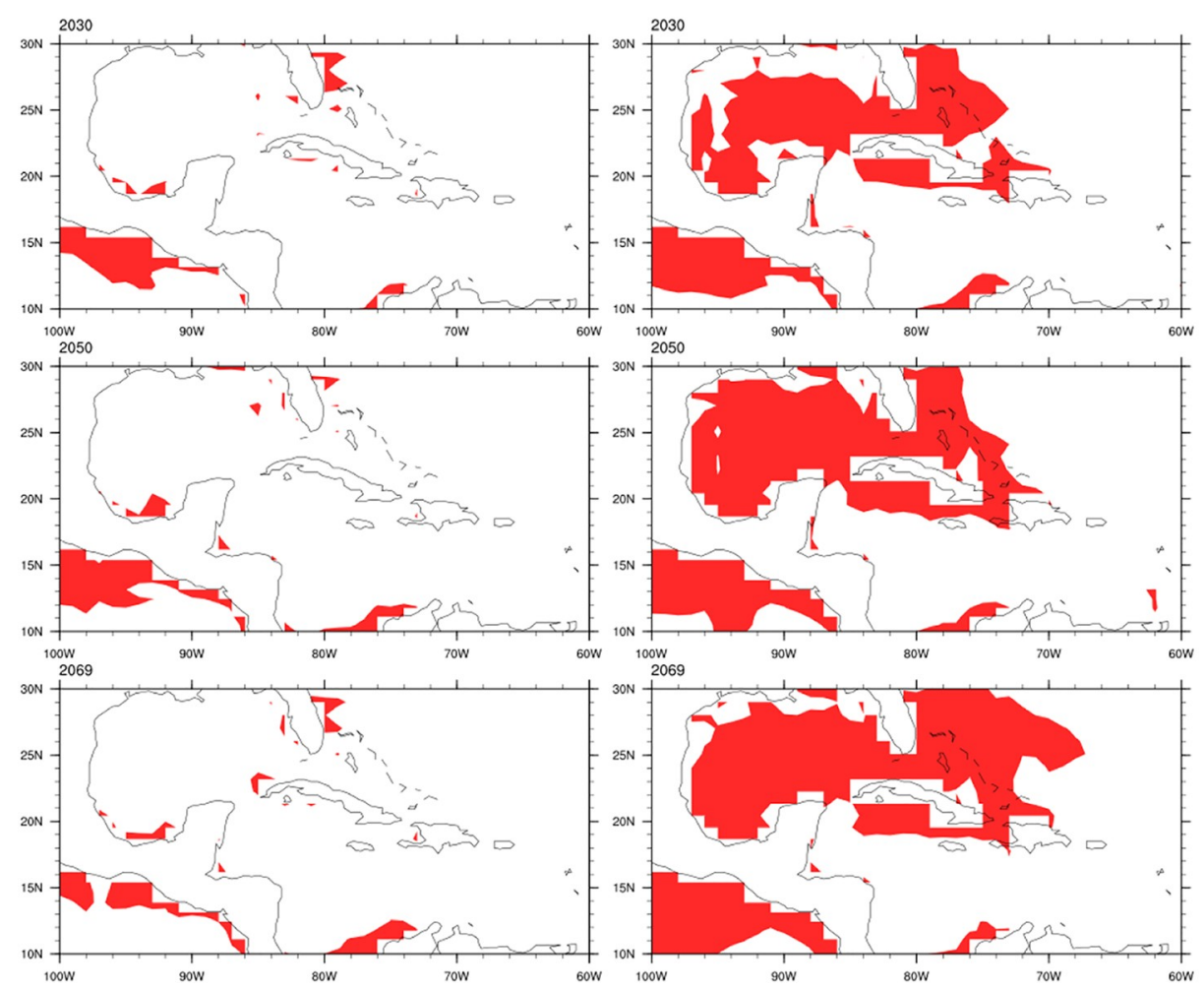

per cent, on average, in the year following a hurricane impact. The frequency of hurricanes is higher in the north and east of the Caribbean Sea than in the south and west, so coral cover in the north and east of the Caribbean Sea impacted by hurricanes has declined at a significantly faster rate than that in the south and west. After hurricane impacts, corals show no evidence of recovery to a pre-storm state for at least eight years, which is roughly equivalent to the average return period of hurricanes in the most hurricane-prone parts of the Caribbean during 1951-2001 (Gardner et al., 2005). Moreover, there was a significant negative correlation $(r=0.72, p<0.01)$ between recruitment estimates and storm severity. Intermediate storm severity resulted in variable levels of recruitment of non-branching corals, while the severest storms resulted in significantly $(p<0.002$, Student's $t$-test) lower recruitment estimates (Crabbe, 2016).

Under stratospheric aerosol geoengineering implementation, the frequency of the strongest Category 5 hurricanes can be reduced significantly compared with the RCP4.5 scenario. Figure 2 shows the projected return period of strongest Category 5 hurricanes under RCP4.5 and geoengineering scenarios (based on Moore et al.'s (2015) prediction). Between 2020 and 2069, under the RCP4.5 scenario, the projected return period of strongest Category 5 hurricanes decreases from 3.828 years to 0.850 year. However, if a stratospheric aerosol geoengineering scheme is implemented during 2020-2069, the projected return 


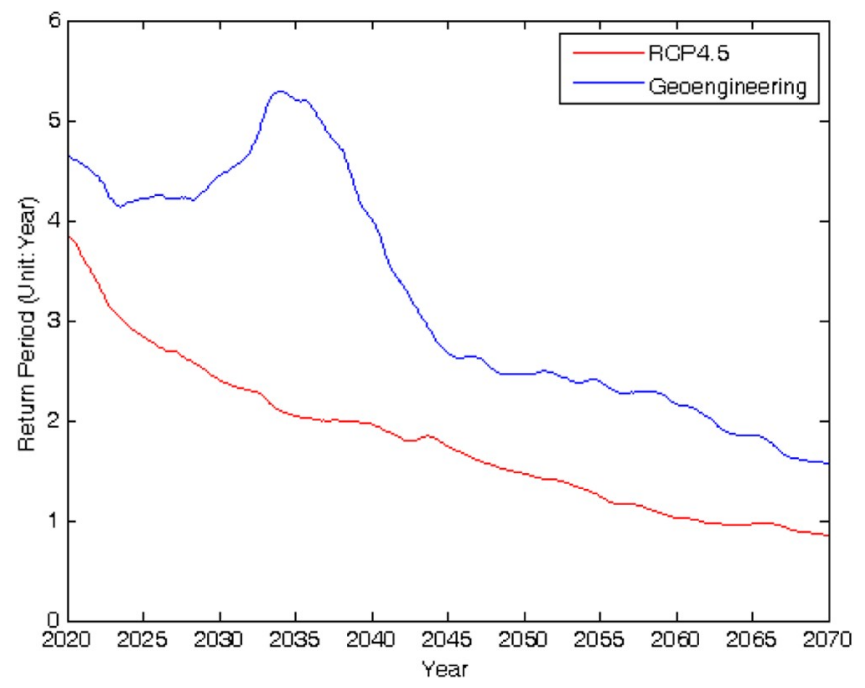

\section{Stratospheric aerosol geoengineering}

period of strongest Category 5 hurricanes decreases from 4.636 years to 1.572 years, and the maximal return period is 5.298 years and occurs in 2034. Although stratospheric aerosol geoengineering with $5 \mathrm{Tg} \mathrm{SO}$ injection per year can significantly increase the hurricane return period in the Caribbean compared with the RCP4.5 scenario, it is still much lower than eight years, the average return period between 1951 and 2001. Since corals need at least eight years to recovery after hurricane impact (Gardner et al., 2005), such hurricanes in the Caribbean Sea, which will occur during 2020-2070, will makes coral recruitment or recovery very challenging, so stratospheric aerosol geoengineering with $5 \mathrm{Tg} \mathrm{SO}$ injection per year injection is not enough to completely mitigate the impacts from hurricane damage.

\section{Coral growth rate}

Reef-building scleractinian corals maintain a symbiotic relationship with photosynthetic zooxanthellae, which limit them to the photic zone. Therefore, the growth of coral reefs depends largely on the amount of light available for photosynthesis. Corals can grow from the surface to depths where there is between 1 and 10 per cent of the surface irradiance (Chalker et al., 1988).

Stratospheric aerosol geoengineering can mitigate climate change by decreasing the amount of solar radiance reaching the Earth. Based on simulations of the HadGEM2-ES climate model, it is clear that in most years between 2020 and 2069, the downward shortwave radiation arriving at the surface of the Caribbean Sea is not significantly reduced between 2020 and 2069 if compared with the RCP4.5 scenario (Figure 3).

As sunlight decreases with water depth, future changes of sea level will also influence coral growth. Since stratospheric aerosol geoengineering can mitigate climate change and cool the earth, it can mitigate future sea level rise. Based on simulations of the HadGEM2-ES climate model, it is clear that in most years between 2020 and 2069, the sea level rise of the Caribbean Sea, calculated as part of the climate model we use, is reduced if compared with the RCP4.5 scenario (Figure 4). The mean sea level rise mitigation from 2020 to 2069 owing to geoengineering implementation is $0.029 \mathrm{~m}$. 
IJCCSM

10,4

\section{8}

Figure 3.

Change of annual mean shortwave radiation (\%) arriving at the surface of the Caribbean Sea if stratospheric aerosol geoengineering is implemented from 2020 to 2069

\section{Figure 4 .}

Sea level rising mitigation in the Caribbean Sea under aerosol geoengineering implementation when compared with the RCP4.5 scenario (units are in $\mathrm{m}$ )
To assess the impact of solar radiation and sea level rise caused by stratospheric aerosol geoengineering implementation, we will use the following model (Bosscher and Schlager, 1992):

$$
G=G_{m} \tanh \left(I_{0} e^{-k z} / I_{k}\right)
$$

where $G_{m}$ is the maximum coral growth rate, $z$ is the depth, $I_{O}$ is surface light intensity (i.e. downward shortwave radiation at the surface), $I_{k}$ is the saturating light intensity and $k$ is the extinction coefficient determined by the turbidity of the reef waters. Combining with observational data in the Caribbean Sea, when $G_{m}=12.5 \mathrm{~mm} \mathrm{yr}^{-1}, k=0.1 \mathrm{~m}^{-1}, I_{O}=2000$ $\mu \mathrm{Em}^{-2}$ and $I_{k}=450 \mu \mathrm{Em}^{-2}$, the model represents maximal limits for coral growth, and when $G_{m}=7.5 \mathrm{~mm} \mathrm{yr}^{-1}, k=0.15 \mathrm{~m}^{-1}, I_{O}=2000 \mu \mathrm{Em}^{-2}$ and $I_{k}=300 \mu \mathrm{Em}^{-2}$, the model represents minimal limits for coral growth (Bosscher and Schlager, 1992).

Compared with the RCP4.5 scenario, HadGEM2-ES simulations show that between 2020 and 2069, stratospheric aerosol geoengineering could reduce annual surface shortwave radiation by 0.895 per cent and mitigate sea level rising by $0.029 \mathrm{~m}$ on average. Figure 5 shows the projected change of maximal/minimal limits for coral growth under stratospheric
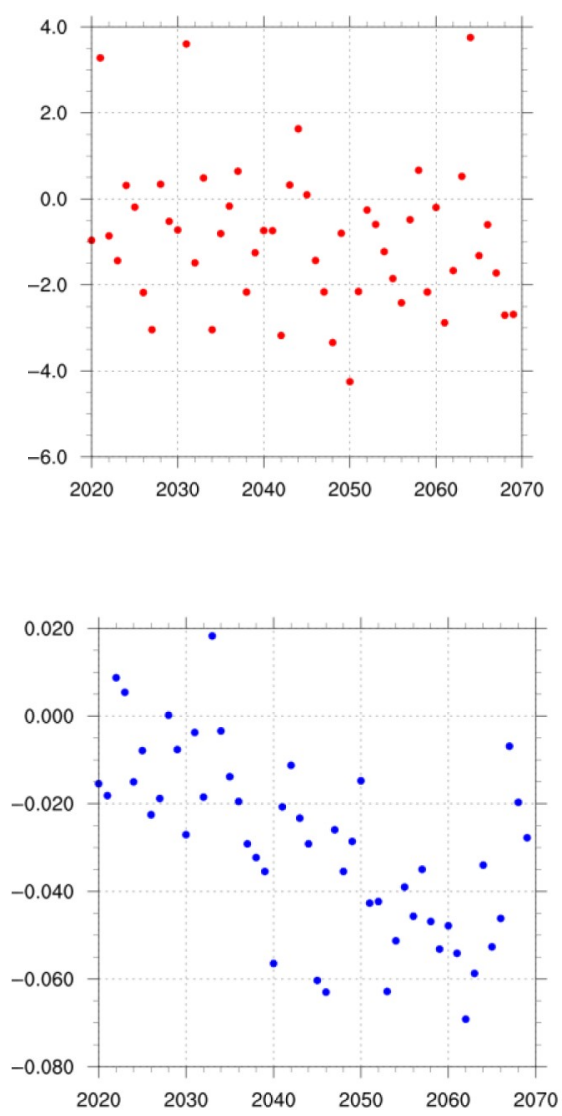
aerosol geoengineering implementation. For depth less than $10 \mathrm{~m}$, minimal/maximal coral growth limits would be reduced by $<0.13$ per cent; when the depth increases from $10 \mathrm{~m}$ to 30 $\mathrm{m}$, the minimal coral growth limits would be reduced by 0.13-0.46 per cent and the maximal limits would be reduced by $0.13-0.59$ per cent. For depths larger than $30 \mathrm{~m}$, the minimal coral growth limits would be reduced by $\sim 0.46$ per cent and the maximal coral growth limits would be reduced by $\sim 0.6$ per cent (Figure 5).

Sea water temperature variation is another important factor for coral growth. Acropora palmata is a model branching coral species in the Caribbean. On the fringing reefs around Discovery Bay off the north coast of Jamaica, there was a predominantly linear relationship between the logarithmic rate of growth of $A$. palmata versus the rate of change of SSTs, over the period 2002-2007, with $R^{2}=0.935$ (Crabbe, 2007):

$$
\text { Log growth rate }=0.1477 * \text { Change of SSTs }+0.0228 \text {. }
$$

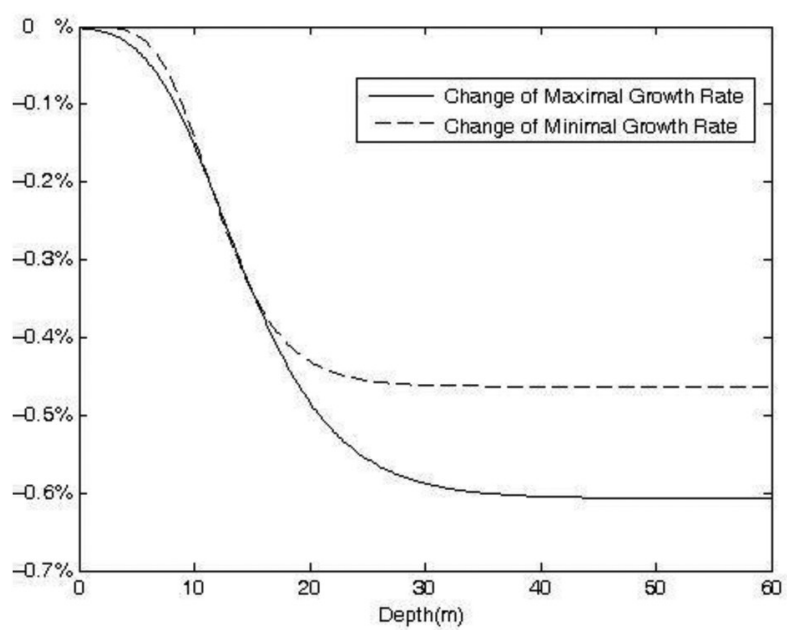

Figure 5.

Projected change of maximal and minimal coral growth ratio under aerosol geoengineering implementation when compared with the RCP4.5 scenario

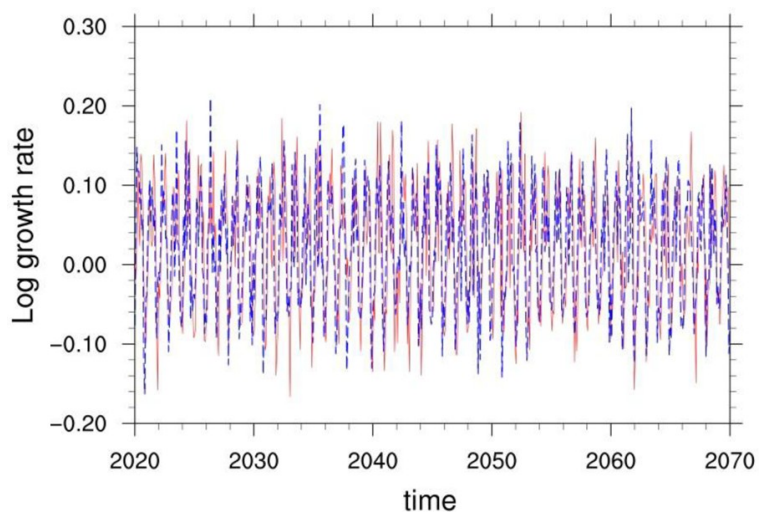

Figure 6. Projected coral growth rate in 20202070 under RCP4.5 (red line) and geoengineering (blue line) scenarios 
IJCCSM

10,4

Based on this formula and using simulated SST from the HadGEM2-ES climate model, we can project future $A$. palmata growth rates under RCP4.5 (red line) and geoengineering (blue line) scenarios (Figure 6). From this, it is clear that when SST is lower than the thermal threshold for coral bleaching, there is little difference in coral growth under RCP4.5 and stratospheric aerosol geoengineering scenarios.

\section{Discussions and conclusions}

Coral reefs provide an environment in which one-third of all marine fish species and tens of thousands of other species are found, and from which 6 million tons of fish are caught annually. Present and future increases in sea temperature are likely to have severe effects on the world's coral reefs within 50 years. Stratospheric aerosol geoengineering has low costs and can rapidly mitigate climate change, so it is viewed as one of the most promising geoengineering approaches to be implemented in the future. In this study, we consider a stratospheric aerosol geoengineering in 2020-2069 with daily injections of $\mathrm{SO}_{2}$ at a rate of 5 $\mathrm{Tg} \mathrm{\textrm {SO } _ { 2 }}$ per year and concentrate its impacts on Caribbean coral reefs, which are currently threatened by climate-induced ocean warming. Stratospheric aerosol geoengineering could significantly mitigate coral bleaching. Under geoengineering implementation, coral bleaching in the Caribbean would not occur, except for some small regions near the southern coastline or east of Florida, while under the RCP4.5 scenario, coral bleaching will occur in most parts of the northern Caribbean Sea. At the same time, any changes in downward solar irradiation, sea level rise and the change of sea temperature variation in the Caribbean Sea caused by geoengineering implementation should have very little impacts on coral growth. For the impact related to severe Category 5 hurricanes, although geoengineering could prolong the return period of hurricanes during 2020-2069, if compared with the RCP4.5 scenario, it may not be enough for corals to recover after hurricane impacts. Therefore, stratospheric aerosol geoengineering with $5 \mathrm{Tg} \mathrm{SO}_{2}$ injection per year may not be enough to ensure full mitigation of climate change for corals in the Caribbean Sea. In addition, stratospheric aerosol geoengineering cannot avert the continued absorption of increasing anthropogenic $\mathrm{CO}_{2}$ emissions by the global ocean, which leads to rising acidity and to decreases in coral calcification and growth.

\section{References}

Baker, A.C., Glynn, P.W. and Riegl, B. (2008), "Climate change and coral reef bleaching: an ecological assessment of long-term impacts, recovery trends and future outlook", Estuarine, Coastal and Shelf Science, Vol. 80 No. 4, pp. 435-471.

Bosscher, H. and Schlager, W. (1992), "Computer simulation of reef growth”, Sedimentology, Vol. 39 No. 3, pp. 503-512.

Boucher, O., Randall, Artaxo, D., Bretherton, P., Feingold, C., Forster, G.P., Kerminen, V., Kondo, M., Liao, Y., Lohmann, H., Rasch, U.P., Satheesh, S., Sherwood, K., Stevens, S.B. and Zhang, X.Y. (2013), "Clouds and aerosols", in Stocker, T.F., Qin D., Plattner G.K., Tignor M., Allen S.K., Boschung J., Nauels A., Xia Y., Bex V. and Midgley P.M. (Eds), Climate Change 2013: The Physical Science Basis. Contribution of Working Group I to the Fifth Assessment Report of the Intergovernmental Panel on Climate Change, Cambridge University Press, Cambridge, New York, NY.

Burke, L.M., Reytar, K., Spalding, M. and Perry, A. (2011), Reefs at Risk Revisited, World Resources Institute, WA, DC.

Budyko, M.I. (1977), “On present day climatic changes”, Tellus, Vol. 29 No. 3, pp. 193-204. 
Chalker, B.E., Barnes, D.J., Dunlop, W.C. and Jokiel, P.L. (1988), "Light and reef building corals", Interdisciplinary Science Review, Vol. 13 No. 3, pp. 222-237.

Crabbe, M.J.C. (2007), "Global warming and coral reefs: modelling the effect of temperature on Acropora palmate colony growth”, Computational Biology and Chemistry, Vol. 31 No. 4, pp. 294-297.

Crabbe, M.J.C. (2009), "Modelling effects of geoengineering options in response to climate change and global warming: implications for coral reefs", Computational Biology and Chemistry, Vol. 33 No. 6, pp. 415-420.

Crabbe, M.J.C. (2016), "The impact of climate change and the environment on coral growth", in Goffredo S. and Dubinsky Z. (Eds), The Cnidaria, past Present and Future: The World of Medusa and Her Sisters, Springer.

Crabbe, M.J.C., Walker, E.L.L. and Stephenson, D.B. (2009), "The impact of weather and climate extremes on coral growth", in Diaz, H., Murnane, R. (Eds), Climate Extremes and Society, Cambridge University Press, Cambridge.

Crutzen, P.J. (2006), "Albedo enhancement by stratospheric sulfur injections: a contribution to resolve a policy dilemma?”, Climatic Change, Vol. 77 Nos 3/4, pp. 211-219.

Eakin, C.M., Morgan, J.A., Heron, S.F., Smith, T.B., Liu, G., Alvarez-Filip, L., Baca, B., Bartels, E., Bastidas, C., Bouchon, C., Brandt, M., Bruckner, A., Bunkley-Williams, L., Cameron, A., Causey, B.D., Chiappone, M., Christensen, T.R.L., Crabbe, M.J.C., Day, O., de la Guardia, E., Díaz-Pulido, G., DiResta, D., Gil-Agudelo, D.L., Gilliam, D., Ginsburg, R., Gore, S., Guzman, H.M., Hendee, J.C., Hernández-Delgado, E.A., Husain, E., Jeffrey, C.F.G., Jones, R.J., Jordán-Dahlgren, E., Kaufman, L., Kline, D.I., Kramer, P., Lang, J.C., Lirman, D., Mallela, J., Manfrino, C., Maréchal, J.P., Marks, K., Mihaly, J., Miller, W.J., Mueller, E.M., Muller, E., Orozco Toro, C.A., Oxenford, H.A., PonceTaylor, D., Quinn, N., Ritchie, K.B., Rodríguez, S., Rodríguez Ramírez, A., Romano, S., Samhouri, J.F., Sánchez, J.A., Schmahl, G.P., Shank, B., Skirving, W.J., Steiner, S.C.C., Villamizar, E., Walsh, S.M., Walter, C., Weil, E., Williams, E.H., Woody Roberson, K. and Yusuf, Y. (2010), "Caribbean corals in crisis: record thermal stress, bleaching, and mortality in 2005”, PLoS One, Vol. 5 No. 11, p. e13969, doi: 10.1371/journal.pone.0013969.

Gardner, T.A., Cote, I.M., Gill, J.A., Grant, A. and Watkinson, A.R. (2003), "Long-term region-wide declines in Caribbean corals”, Science (New York, N.Y.), Vol. 301 No. 5635, pp. 958-960.

Gardner, T.A., Cote, I.M., Gill, J.A., Grant, A. and Watkinson, A.R. (2005), "Hurricanes and Caribbean coral reefs: impacts, recovery patterns, and role in long-term decline”, Ecology, Vol. 86 No. 1, pp. 174-184.

Hoegh-Guldberg, O. (1999), "Climate change, coral bleaching and the future of the world's coral reefs", Marine and Freshwater Research, Vol. 50 No. 8, pp. 839-866.

Isabelle, M.C., Precht, W.F., Aronson, R.B. and Gardner, T.A. (2013), "Is Jamaica a good model for understanding Caribbean coral reef dynamics?", Marine Pollution Bulletin, Vol. 76, pp. 28-31.

Israel, Y.A. (2010), Problem of Preserving Modern Climate, Materials of a Permanent Seminar on the Development of the Union State under the Parliamentary Assembly of the Union of Belarus and Russia: Hydrometeorological Security of the Union State under Changing Climate Conditions, pp. 36-46

Kravitz, B., Robock, A., Boucher, O., Schmidt, H., Taylor, K.E., Stenchikov, G. and Schulz, M. (2011), "The Geoengineering Model Intercomparison Project (GeoMIP)", Atmospheric Science Letters, Vol. 12 No. 2, pp. 162-167.

Miththapala, S. (2006), "Conserving medicinal species”, Securing a Healthy Future, IUCN, available at: https://portals.iucn.org/library/efiles/documents/2006-022.pdf

Moore, J.C., Grinsted, A., Guo, X., Yu, X., Jevrejeva, S., Rinke, A., Cui, X., Kravitz, B., Lenton, A., Watanabe, S. and Ji, D. (2015), "Atlantic hurricane surge response to geoengineering", 
IJCCSM

10,4

Proceedings of the National Academy of Sciences, Vol. 112 No. 45, pp. 13794-13799, doi: 10.1073/ pnas.1510530112.

Robock, A., Marquardt, A., Kravitz, B. and Stenchikov, G. (2009), "Benefits, risks, and costs of stratospheric geoengineering”, Geophysical Research Letters, Vol. 36 No. 19, doi: 10.1029/ 2009GL039209.

Schutte, V.G.W., Selig, E.R. and Bruno, J.F. (2010), "Regional spatio-temporal trends in Caribbean coral reef benthic communities", Marine Ecology Progress Series, Vol. 402, pp. 115-122.

Zhang, Z., Moore, J.C., Huisingh, D. and Zhao, Y. (2015), "Review of geoengineering approaches to mitigating climate change", Journal of Cleaner Production, Vol. 103, pp. 898-907.

\section{About the authors}

Zhihua Zhang is a Full Professor at Beijing Normal University. His research focuses on climate change and related issues. Zhang has published more than 50 first-authored articles and 3 firstauthored books in Elsevier, DeGruyter and Springer. He currently serves as an associate editor/ editorial board member of Arabian Journal of Geosciences (Springer, IF = 1.2), Journal of Cleaner Production (Elsevier, IF = 5.7), International Journal of Global Warming (Indersciences, IF = 0.6) and EURASIP Journal on Advances in Signal Processing (Springer, IF = 1.9).

Andy Jones is a senior climate modeler at Met Office Hadley Centre.

M. James C. Crabbe is a former Editor-in-Chief of Computational Biology and Chemistry (Elsevier, IF $=1.0$ ). His research focuses on coral reef ecology and climate change, and he has published more than 130 articles. M. James C. Crabbe is the corresponding author and can be contacted at: james. crabbe@wolfson.ox.ac.uk

For instructions on how to order reprints of this article, please visit our website: www.emeraldgrouppublishing.com/licensing/reprints.htm Or contact us for further details: permissions@emeraldinsight.com 